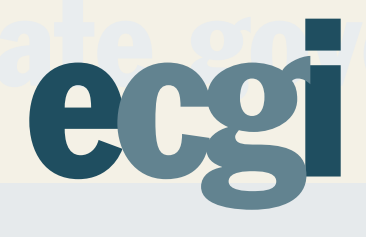

\title{
Emergency Measures for Equity Trading: The Case Against Short-Selling Bans and Stock Exchange Shutdowns
}

Law Working Paper N 513/2020

May 2020

\section{Luca Enriques}

University of Oxford, EBI and ECGI

Marco Pagano

University of Naples Federico II, CSEF, EIEF, CEPR and ECGI

(C) Luca Enriques and Marco Pagano 2020. All rights reserved. Short sections of text, not to exceed two paragraphs, may be quoted without explicit permission provided that full credit, including (C) notice, is given to the source.

This paper can be downloaded without charge from: http://ssrn.com/abstract_id=03598151 https://ecgi.global/content/working-papers 


\title{
Emergency Measures for Equity Trading: The Case Against Short-Selling Bans and Stock Exchange Shutdowns
}

Working Paper N 513/2020

May 2020

\author{
Luca Enriques \\ Marco Pagano
}

This chapter is based on two separate posts: Luca Enriques, 'Stock Exchange Shutdowns in the Time of Coronavirus' (Oxford Business Law Blog, 12 March 2020) <https://www.law.ox.ac.uk/business-law-blog/ blog/2020/03/stock-exchange-shutdowns-time-coronavirus>, and Marco Pagano, 'Should We Ban Short Sales in a Stock Market Crash?' (Oxford Business Law Blog, 13 March 2020) <https://www.law.ox.ac.uk/businesslaw-blog/blog/2020/03/should-we-ban-short-sales-stock-market-crash>. All URLs were last accessed on 27 April 2020. We wish to thank Kristin Van Zwieten for precious comments to one of the blog posts this chapter is based on.

(C) Luca Enriques and Marco Pagano 2020. All rights reserved. Short sections of text, not to exceed two paragraphs, may be quoted without explicit permission provided that full credit, including (C) notice, is given to the source. 


\begin{abstract}
After the Covid-19 crisis struck, equity prices abruptly plunged across the world. The clear prospect of an almost unprecedented decrease in supply and demand, coupled with extreme uncertainty about the longer-term prospects for the economy worldwide, justified the price adjustments. Yet, in conditions of plummeting prices and high volatility, policymakers around the world felt under pressure to do something' to stop the downward trend in market prices. As was the case during the financial crises of 2008-09 and 2011-12, these pressures have quickly led to the adoption of market-wide short-selling bans. In addition, both in Europe and in the US, there have been calls for an even more drastic measure: a lasting 'stock exchange holiday'. This chapter reviews the evidence on the effects of shortselling bans during the financial crisis and discusses the merits of stock exchange holidays and concludes that neither of these measures bring benefits to financial markets.
\end{abstract}

Keywords: Covid-19 Crisis, Equity Markets, Securities Regulation, Short-selling bans, Stock Exchanges.

JEL Classifications: G18, K22

\title{
Luca Enriques*
}

Allen \& Overy Professor of Corporate Law

University of Oxford, Faculty of Law

St.Cross Building, St. Cross Road

Oxford, OX1 3UL, United Kingdom

phone: +44 1865289751

e-mail: luca.enriques@law.ox.ac.uk

\section{Marco Pagano}

Professor of Finance

University of Naples Federico II, Department of Economics and Statistics

Via Cintia Monte S. Angelo

80126 Napoli, Italy

phone: +39081675306

e-mail: marco.pagano@unina.it

${ }^{*}$ Corresponding Author 


\title{
Emergency Measures for Equity Trading: The Case Against Short-Selling Bans and Stock Exchange Shutdowns
}

\author{
Luca Enriques \& Marco Pagano ( $\left.{ }^{*}\right)$ \\ Forthcoming in \\ Christos Gortsos and Wolf-Georg Ringe (eds), \\ Global Pandemic Crisis and Financial Stability
}

\begin{abstract}
After the Covid-19 crisis struck, equity prices abruptly plunged across the world. The clear prospect of an almost unprecedented decrease in supply and demand, coupled with extreme uncertainty about the longer-term prospects for the economy worldwide, justified the price adjustments. Yet, in conditions of plummeting prices and high volatility, policymakers around the world felt under pressure 'to do something' to stop the downward trend in market prices. As was the case during the financial crises of 2008-09 and 2011-12, these pressures have quickly led to the adoption of market-wide short-selling bans. In addition, both in Europe and in the US, there have been calls for an even more drastic measure: a lasting 'stock exchange holiday'. This chapter reviews the evidence on the effects of short-selling bans during the financial crisis and discusses the merits of stock exchange holidays and concludes that neither of these measures bring benefits to financial markets.
\end{abstract}

Keywords: Covid-19 Crisis, Equity Markets, Securities Regulation, Short-selling bans, Stock Exchanges.

JEL: G18, K22

(*) University of Oxford, EBI and ECGI, and University of Naples Federico II, CSEF, EIEF, CEPR and ECGI, respectively. Luca Enriques was a Consob Commissioner from 2007 to 2012. This chapter is based on two separate posts: Luca Enriques, 'Stock Exchange Shutdowns in the Time of Coronavirus' (Oxford Business Law Blog, 12 March 2020) <https://www.law.ox.ac.uk/business-law-blog/blog/2020/03/stock-exchange-shutdowns-timecoronavirus >, and Marco Pagano, 'Should We Ban Short Sales in a Stock Market Crash?' (Oxford Business Law Blog, 13 March 2020) < https://www.law.ox.ac.uk/business-law-blog/blog/2020/03/should-we-ban-short-salesstock-market-crash>. All URLs were last accessed on 27 April 2020. We wish to thank Kristin Van Zwieten for precious comments to one of the blog posts this chapter is based on. 


\section{Introduction}

At the outbreak of the Covid-19 crisis, traded financial assets prices abruptly plunged. The clear prospect of an almost unprecedented decrease in supply and demand in the near future given the lockdowns, coupled with extreme uncertainty about the longer-term prospects for the economy world-wide, justified such sharp price adjustments. Yet, in conditions of plummeting prices and high volatility, policymakers around the world felt under pressure 'to do something' to stop the downward trend in market prices. ${ }^{1}$ During the financial crises of 2008-09 and 201112 , these pressures led to the adoption of short-selling bans. During the present crisis, a number of European national securities regulators, with the approval of the European Securities and Markets Authority (ESMA), reinstated such bans. ${ }^{2}$ In addition, both in Europe and in the US, there have been calls for an even more drastic measure: a total shutdown of stock exchanges. ${ }^{3}$ To be clear, not just 15-minute circuit breakers, like the US exchanges have in place, but a lasting 'stock exchange holiday'. This chapter reviews the evidence on the effects of shortselling bans during the financial crisis and discusses the merits of stock exchange holidays.

\section{How Effective Are Bans on Short Sales?}

Few things are more predictable than loud demands for regulatory interventions to 'stop speculation' when stock market prices plunge: in these days, as in any recent stock market crash, we hear politicians and commentators inviting regulators to enact interventions spanning from stock trading suspension to a short sales ban. In the past, stock market regulators typically bowed to such demands: banning short sales is almost their 'Pavlovian response' when faced with widespread drop in stock market prices.

Over the last twenty years, unfortunately there has been no shortage of crises, so that we have had the opportunity to observe this 'Pavlovian response' of regulators repeatedly and in many countries. On 19 September 2008, immediately after the Lehman collapse shook investors' confidence in the soundness of banks and brought down the prices of their shares, the Securities and Exchange Commission (SEC) banned short-selling of shares in banks and

\footnotetext{
${ }^{1}$ See Luca Enriques, 'Regulators' Response to the Current Crisis and the Upcoming Reregulation of Financial Markets: One Reluctant Regulator's View’, (2009) 4 University of Pennsylvania J of International L 1147-51. 2 See infra $n 13$.

${ }^{3}$ See Alexandra Andhov, 'Covid-19: Should We Close Stock Exchanges?' (Oxford Business Law Blog, 24 April 2020) < https://www.law.ox.ac.uk/business-law-blog/blog/2020/04/covid-19-should-we-close-stock-exchanges $>$; Matt Levine, 'Everyone Could Use a Little Break' (Bloomberg, 27 March 2020) $<$ https:/www.bloomberg.com/news/newsletters/2020-03-27/money-stuff-everyone-could-use-a-little-break $>$ (discussing the issue).
} 
financial companies in the US. This ban was quickly imitated by the majority of other countries: some only banned 'naked short sales', in which the seller does not borrow shares to deliver them to the buyer during the settlement period; others also banned covered short sales, in which the seller protects himself by borrowing the shares. More recently, during the sovereign debt crisis of 2011-12, regulators in most eurozone countries have reacted in the same way to share prices drops, especially those in the banking sector.

These hasty interventions, while varying from country to country in intensity, scope and duration, were invariably presented as aimed at restoring the orderly functioning of the markets and avoiding unwarranted drops in stock prices, and their destabilizing effects. For example, in 2008 the SEC justified its intervention with these words: 'unbridled short selling is contributing to the recent sudden price declines in the securities of financial institutions unrelated to true price valuation' ${ }^{4}$ In the UK, the Financial Services Authority motivated the short-selling ban it introduced on 18 September 2008 for financial stocks as follows: 'sharp share price declines in individual banks were likely to lead to pressure on their funding and thus create a self-fulfilling loop'. ${ }^{5}$ Similarly, in 2012 the Spanish stock market regulator (CNMV) explained its decision to retain the ban introduced in 2011 arguing that "failure to ban short sales would heighten uncertainty', and that accordingly keeping the ban was 'absolutely necessary to ensure the stability of the Spanish financial system and capital markets'. ${ }^{6}$ In short, the conditioned reflex of the regulator rests on this argument: in times of crisis, stock prices fall below their 'true valuation', which can destabilize banks and therefore the financial system. By prohibiting short-selling, we prevent too pessimistic investors from 'expressing their opinions' on the market regarding the value of the shares, hence we avoid the destabilizing undervaluation that would follow.

While apparently sensible, this argument has serious flaws, both in principle and in fact. First, the argument assumes that regulators know better than the market what the "true valuation' of securities is, better than the thousands of investors who spend huge resources every day to also try to calculate such true valuations, so as to buy undervalued securities and sell overvalued ones. But if that is the case, why don't the authorities that oversee security

\footnotetext{
${ }^{4}$ SEC, 'SEC Halts Short Selling of Financial Stocks to Protect Investors and Markets', SEC Press Release 2008211 (19 September 2008) <https://www.sec.gov/news/press/2008/2008-211.htm>.

5 FSA, 'Short Selling', Discussion Paper 09/1 (February 2009) <https://www.sbai.org/wpcontent/uploads/2016/04/fsa short selling 2009.pdf $\$$.

${ }^{6} \mathrm{CNMV}$, 'Decision by The $\overline{\mathrm{C}} \mathrm{NMV}$ to Impose, Effective Immediately and for a Period of 3 Months, Restrictions on Short Selling and Similar Transactions under Article 85.2.J) of the Securities Market Act and Article 20 of Regulation (EU) 236/2012, due to the Existence of Exceptional Circumstances' (1 November 2012) $<$ www.cnmv.es/loultimo/prorroga $\% 201 \% 20$ nov en.pdf $>$.
} 
markets intervene even when prices rise above 'true valuations', before the market crashes? If we ban short sales to prevent unwarranted price drops, we should symmetrically ban margin trading (the borrowing of money to buy shares) leading to unwarranted security market booms.

Second, the empirical evidence that has accumulated over the years, especially in the last two decades, shows that the ban on short-selling is neither able to support security prices, nor to make banks more stable. In a 2013 article by one of us and Alessandro Beber, ${ }^{7}$ we analysed daily data on 16,491 shares in 30 countries between January 2008 and June 2009. Our results indicate that the short-selling bans implemented over those months did not go hand in hand with increases or lower drops in the stock prices, except in the United States in the two weeks following the application of the ban, an exception probably due to the simultaneous announcement of bank bailouts by the United States government. In other countries, where the bans were not accompanied by announcements of bank bailouts, or also targeted non-bank shares, or did not target bank shares at all, the bans on short-selling do not seem to have supported security prices. The estimates indicate that banning naked short sales did not have significant effects on share prices, and banning covered short sales even made them decrease. A subsequent work carried out by one of us with Alessandro Beber, Daniela Fabbri and Saverio Simonelli in 2018 also shows that, contrary to what regulators expected, banks whose securities were subject to short-selling bans even featured an increased probability of insolvency, compared to other banks of similar risk and size but exempt from the ban. ${ }^{8}$

An obvious criticism of these findings is that short-selling bans are not imposed randomly, but in situations of high stock price volatility and to the stocks of distressed companies, so the correlation between short-selling bans and bank instability cannot be interpreted as a causal relationship. To take the endogeneity of short sales bans into account, Beber et al. (2018) instrument the 2011 ban decisions with regulators' propensity to impose a ban in the 2008 crisis, that is, use the data from the first crisis to infer the propensity of regulators to impose a short-selling ban in the second crisis. The results from this exercise indicate that, once one takes the endogeneity of the policy response into account, short-sale bans are estimated to be even more destabilizing for the financial institutions whose share are banned.

\footnotetext{
${ }^{7}$ Alessandro Beber and Marco Pagano, 'Short-Selling Bans Around the World:Evidence from the 2007-09 Crisis' (2013) 68 J Finance 343.

8 Alessandro Beber and others, 'Short-Selling Bans and Bank Stability' (2017) $<$ https://ssm.com/abstract $=2710371>$.
} 
Third, the empirical evidence shows that short-selling bans have significant negative side effects. They tend to considerably reduce the liquidity of the markets, because they are accompanied by an increase in bid-ask spreads, especially for smaller companies: reducing market liquidity is particularly damaging in crisis conditions, when liquidity is already in short supply and investors seek it desperately. Furthermore, these bans substantially reduce the informational efficiency of security markets, that is, the speed with which new information is impounded in prices: trying to 'silence the pessimists' makes everyone less informed and thus increases market uncertainty. This not only suppresses the negative information that shortsellers initially bring to the market, but also the positive one that they convey once the crisis hits the bottom: at that stage, to profit from their downward bets, short-sellers have to enter the market and buy, thus issuing the signal that the bottom has been reached.

Finally, short-selling bans make it difficult for investors wishing to take bets on specific stocks to hedge against market-wide movements: hedge funds betting that individual stocks will outperform the market, often protect against the risk that a market-wide or industry-wide downward trend will negatively affect their trade by going short on a basket of shares in the same market or industry. If short positions are prohibited, this is not possible and hence there will be fewer traders willing to exploit their stock-specific information, and also on this account price discovery will be impaired.

The conclusion is therefore well summarized by the words pronounced on 31 December 2008 by the former president of the SEC, Christopher Cox: 'Knowing what we know now, I believe on balance the commission would not do it again. The costs (of the short-selling ban on financials) appear to outweigh the benefits. ${ }^{9}$

Policymakers in a number of European countries appear not to have learnt that lesson. Italian, French, Austrian, Greek, Belgian, and Spanish securities regulators all introduced temporary bans on short-selling in March 2020. ${ }^{10}$ Italy's ban was for three months, while other regulators started with a one-month ban and extended it for another month before it elapsed. ${ }^{11}$

9 Rachelle Younglai, 'SEC Chief Has Regrets over Short-selling Ban' (Reuters, 31 December 2008) $<$ https://www.reuters.com/article/us-sec-cox/sec-chief-has-regrets-over-short-selling-banidUSTRE4BU3GG20081231>.

${ }^{10}$ See Philip Stafford, Laurence Fletcher, David Keohane, 'Europe Extends Short-Selling Bans despite Hedge Fund Pressure' Financial Times (15 April 2020) <https://www.ft.com/content/d615a15d-c524-4383-b829$4 \mathrm{f} 1 \mathrm{a} 244 \mathrm{db} 28 \mathrm{a}>$.

$11 \mathrm{Id}$. 
As required by the Short-Selling Regulation, ${ }^{12}$ ESMA authorized all of the bans ${ }^{13}$ and, prior to that, temporarily required holders of net short positions in shares traded on a European Union (EU) regulated market to notify the relevant national competent authority (NCA) if the position reaches or exceeds $0.1 \%$ of the issued share capital after the entry into force of the decision. ${ }^{14}$ By raising the costs of holding a net short position of that size, such measure also acts as an indirect curb on short-selling.

\section{Should Exchanges Be Shut Down?}

If stocks were still traded in pits, stock exchanges would have been shut down everywhere. A bunch of men shouting and feverishly passing each other sheets of papers ${ }^{15}$ would have spread coronavirus faster than the now infamous Korean sect. ${ }^{16}$

But stock exchange trading was automated everywhere long ago. ${ }^{17}$ Nowadays, the only virus that can be transmitted by trading shares is panic selling. Is that an even better reason for shutting down stock markets, as, among others, some high-profile Italians politicians suggested in March 2020 ?

\footnotetext{
${ }^{12}$ Regulation (EU) No 236/2012 of the European Parliament and of the Council of 14 March 2012 on Short Selling and Certain Aspects of Credit Default Swaps, [2012] OJ L86/1 (EU Short Selling Regulation), Art. 27.

${ }^{13}$ See ESMA, 'Opinion of the European Securities and Markets Authority of 17 March 2020 on a Proposed Emergency Measure by the Commissione Nazionale per le Società e la Borsa under Section 1 of Chapter V of Regulation (EU) No 236/2012' (17 March 2020) <https://www.esma.europa.eu/press-news/esma-news/esmaissues-positive-opinion-short-selling-ban-italian-consob-1>; ESMA,'Opinion of the European Securities and Markets Authority of 18 March 2020 on a Proposed Emergency Measure by the Autorité des Marchés Financiers under Section 1 of Chapter V of Regulation (EU) No 236/2012' (18 March 2020) $<$ https://www.esma.europa.eu/press-news/esma-news/esma-issues-positive-opinion-short-selling-ban-frenchamf>; ESMA, 'Opinion of the European Securities and Markets Authority of 19 March 2020 on a Proposed Emergency Measure by the Hellenic Capital Market Commission under Section 1 of Chapter V of Regulation (EU) No 236/2012' (18 March 2020) <https://www.esma.europa.eu/press-news/esma-news/esma-issuespositive-opinions-bans-net-short-positions-belgian-fsma-and-greek>; ESMA, 'Opinion of the European Securities and Markets Authority of 19 March 2020 on a Proposed Emergency Measure by the Financial Securities and Markets Authority under Section 1 of Chapter V of Regulation (EU) No 236/2012' (18 March 2020) $<$ https://www.esma.europa.eu/press-news/esma-news/esma-issues-positive-opinions-bans-net-short-positionsbelgian-fsma-and-greek>; ESMA, 'ESMA Issues Positive Opinions on Short Selling Bans by Austrian FMA, Belgian FSMA, French AMF, Greek HCMC and Spanish CNMV', Press Release (15 April 2020) $<$ https://www.esma.europa.eu/press-news/esma-news/esma-issues-positive-opinions-short-selling-bans-austrianfma-belgian-fsma>.

${ }^{14}$ ESMA, 'ESMA Requires Net Short Position Holders to Report Positions of $0.1 \%$ and Above' Press Release (16 March 2020) <https://www.esma.europa.eu/press-news/esma-news/esma-requires-net-short-positionholders-report-positions-01-and-above $>$.

15 As famously epitomized in the orange juice futures trading scene at the end of Trading Places (see https://www.youtube.com/watch?v=obAoPP1bdIM).

16 Billy Perrigo, 'South Korean “Cult” at Center of Local Coronavirus Outbreak' Time (20 February 2020) $<$ https://time.com/5787898/south-korea-coronavirus-sect $>$.

${ }^{17}$ Not completely, though. Some exchanges still have 'floors' where a small amount of trading still takes place. Needless to say, in response to the Covid-19 pandemic, such floors have been shut down across the globe in March 2020. See eg Steven Zeitchik, 'With Stock-exchange Floor Closed, Traders and Investors Grapple with Uncertainty' Washington Post (8 April 2020) < https://www.washingtonpost.com/business/2020/04/08/withstock-exchange-floor-closed-traders-investors-grapple-with-uncertainty/>.
} 
Reassuringly, back then the Italian Government ignored the suggestion and the Italian securities regulator, Consob, responded to such calls by appealing to reasonableness and reminding everyone that ' $[\mathrm{t}]$ he trading halt of all stock market negotiations ... would be a decision that would switch off the price indicator without removing the causes, generating market problems that are not easy to solve in the immediate future.' ${ }^{18}$ In other words: a stock exchange shutdown is the financial equivalent of getting rid of the thermometer when it signals fever: the only outcome is that it becomes more difficult to understand how serious the flu is and how it is evolving.

A stock exchange shutdown also means putting more pressure on other financial instruments whose prices are correlated to that of shares. Think of an investor who holds both Italian equity and Italian Treasury bonds in their portfolio. If they assume that, Covid-19 will have a greater impact in Italy than elsewhere, perhaps because of its higher sovereign debt-toGDP ratio than in neighbouring countries, they might want to reduce their exposure to the country. And if they were not allowed to sell the equity, to compensate for that they would sell more Treasury bonds, thereby contributing to the rise in their interest rate. Should Italy then also ban Treasury bond trading? Treasury bonds are traded outside Italy as well. A shutdown limited to domestic trading venues would only drain the bonds' liquidity and hence make it more onerous for the state to issue new bonds (something the Italian state does every few weeks). It would thus lead to the Government (hence, Italian taxpayers) having to pay higher interest rates in the attempt of stopping downward speculative pressures on the equity market. To put it another way, attempting to curb the losses of the minority of Italian citizens who are invested in shares ${ }^{19}$ would be at the expense of taxpayers generally.

Additionally, the result of shutting down the stock exchange is to make the savings of those who are invested in it unavailable at a time of emergency, which is exactly when savers/investors may need to convert them into cash. This would be true not only for those who have bought shares directly, but also for those who have done so via mutual funds: how can an asset manager accept withdrawal requests if it cannot sell the assets in the fund's portfolio and it is impossible to determine their value? In all likelihood the asset manager would make use

\footnotetext{
18 Consob, Press Release (9 March 2020) <http://www.consob.it/web/consob-and-its-activities/news-in-detail//asset publisher/kcxlUuOyjO9x/content/press-release-9-march-2020-hp/718268>.

19 The Italian pension system is pay-as-you-go and Italian pension funds' exposure to Italian equity at the end of

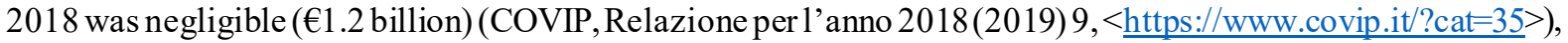
or 0.22 percent of the Italian stock exchange capitalization at the same date (source: $<$ https://www.borsaitaliana.it/borsaitaliana/ufficio-stampa/comunicati-stampa/2018/review-mercati-2018.htm>).
} 
of its power, according to the contract with the unitholders, to suspend withdrawals until the stock exchange reopens.

Finally, the most intractable problem with shutting down exchanges is the fact that sooner or later they have to be reopened. In the present circumstances, for how long should stock exchanges be closed? The problem being coronavirus, a few days would make no difference, as the experience in Sri Lanka and the Philippines in mid-March showed. ${ }^{20}$ Should they stay closed until the end of lockdowns? Until levels of economic uncertainty go back to 'normal'? ${ }^{21}$

To have an impact, stock exchange shutdowns would likely have to go on for weeks and weeks. If you suppress investors' liquidity needs for such a long period, the downward pressure once the stock exchange reopens will be even stronger. Worse, were the stock exchange shutdown not to involve all or a great majority of world stock exchanges (which is highly unlikely), the precedent would be established that the stock exchange of a given country may shut down for weeks in the case of an emergency: investors, both domestic and offshore, would have to factor in a new kind of illiquidity risk, which will make it less attractive to hold shares listed on that stock exchange and will therefore require investors to rebalance their portfolios. Again, when the shutdown ends, this additional reason for selling would increase the downward pressure on prices. In addition to the temporary liquidity shock, the demand for shares listed on shutdown stock exchanges would decrease for the longer term as well, raising firms' cost of capital.

In truth, however, at least in Europe all of this is financial regulation fiction: as Consob's clarified, ${ }^{22}$ individual regulators in Europe lack the power to shut down an entire stock exchange. Even a shutdown through an emergency law by a national Government would be unlikely to apply to trading activity on offshore trading venues, where that country's shares could well continue trading: an extraterritorial ban would likely be against EU rules, impossible

\footnotetext{
20 See Chad Bray_and Alison Tudor-Ackroyd, 'To Trade or to Halt? That is the Question Confounding Global Markets as Stock Indexes Plunge amid Pandemic' South China Morning Post (24 March 2020)

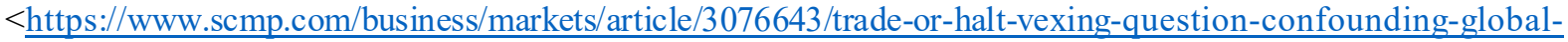
markets-stock $>$ (reporting that the Colombo and the Manila stock exchanges shut down for a few days in midMarch and recorded heavy losses on the day the reopened).

21 At the time of post-Lehman temporary bans on short-selling (2008-09), Consob's commissioners were convened, before they elapsed, to decide whether to extend them. They repeatedly renewed them, in the fear that, otherwise, Consob would be held politically liable should downward pressures on prices resume. The dynamics will be the same today for countries that have introduced temporary short-selling bans and would be the same for those that shut down markets altogether. It is, or would be, difficult for securities regulators, should positive developments in the fight against the virus and in economic conditions not materialise soon enough (as everyone hopes), to decide that short-selling, or trading altogether, should resume. Hence, political considerations play against a rapid return to trading rules normality.

${ }^{22}$ See Consob (n 16).
} 
to enforce, or both. The only effect of such an emergency law would thus be of reducing, but not halting, trading. That would have a strong negative impact on liquidity, increase volatility, and raise the cost of executing transactions. The symptoms of panic selling would still be visible and the lower trading volumes would even amplify them.

Does that mean that the EU should amend its regulations on trading venues to grant regulators the power to shut down exchanges in times of severe crisis? We hope the arguments developed above are sufficient to support a negative answer to this question.

\section{Conclusion}

As they did in previous crises, securities regulators have issued bans on short-selling in the face of sharp drops in stock prices, despite sound theoretical arguments and consistent empirical evidence justifying the proposition that these measures are pointless, if not counterproductive. But at least it is reassuring that, so far, regulators have not seriously considered a full shutdown of stock exchanges as a response to the current crisis.

As regards both short-selling bans and stock exchange shutdowns, the old saw 'don't shoot the messenger' holds. This rule should apply to messengers motivated by greed no less than to others, and to messengers carrying bad news no more than to those bringing good ones: after all, how rational would it be to punish a doctor that diagnoses a serious disease but applaud one that issues a clean bill of health? Or to refuse paying for the former's services, on account that in this fashion he would be making money out of the misfortune of his patients? 


\section{about ECGI}

The European Corporate Governance Institute has been established to improve corporate governance through fostering independent scientific research and related activities.

The ECGI will produce and disseminate high quality research while remaining close to the concerns and interests of corporate, financial and public policy makers. It will draw on the expertise of scholars from numerous countries and bring together a critical mass of expertise and interest to bear on this important subject.

The views expressed in this working paper are those of the authors, not those of the ECGI or its members. 


\section{ECGI Working Paper Series in Law}

\section{Editorial Board}

Editor

Consulting Editors

Editorial Assistant
Amir Licht, Professor of Law, Radzyner Law School, Interdisciplinary Center Herzliya

Horst Eidenmüller, Freshfields Professor of Commercial Law, University of Oxford

Martin Gelter, Professor of Law, Fordham University School of Law

Geneviève Helleringer, Professor of Law, ESSEC Business

School and Oxford Law Faculty

Curtis Milhaupt, Professor of Law, Stanford Law School

Niamh Moloney, Professor of Law, Department of Law, London

School of Economics and Political Science

Úna Daly, ECGI Working Paper Series Manager 


\section{Electronic Access to the Working Paper Series}

The full set of ECGI working papers can be accessed through the Institute's Web-site (https://ecgi.global/content/working-papers) or SSRN:

Finance Paper Series http://www.ssrn.com/link/ECGI-Fin.html

Law Paper Series http://www.ssrn.com/link/ECGI-Law.html 